SUSTAINABLE FORESTRY

COLLECTION 79-80, 2019
ODRŽIVO ŠUMARSTVO

ZBORNIK RADOVA 79-80, 2019

UDK UDK 630:620.91(497.11 Lazarevac)

UDK $630 * 238$ (497.11 Lazarevac)

Original scientific paper

\title{
SELECTION OF POTENTIAL AREAS FOR THE ESTABLISHMENT OF FOREST PLANTATIONS FOR ENERGY NEEDS - THE CASE OF LAZAREVAC MUNICIPALITY
}

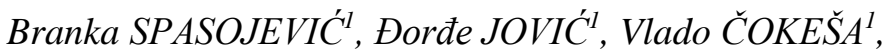 \\ Jelena UROŠEVIĆ ${ }^{l}$, Filip JOVANOVIĆ ${ }^{l}$
}

\begin{abstract}
The needs for energy sources in Serbia are constantly increasing. Wood as the most important energy source is not only used for energy purposes, but also for the wood industry, and it is clear that pressure on the resource is increasing. According to FAO methodology, the estimated energy potential of the available biomass derived from forests and wood processing industry in Serbia amounts to 1.53 Mtoelyear (BrašanacBosanac et al., 2018). In 2016, the Institute of Forestry in Belgrade carried out a preliminary study on the establishment of forest plantations for energy needs. The municipality of Lazarevac was selected as a pilot project for the establishment of forest plantations for energy purposes. It was estimated that this municipality, given its geographical position and ecological conditions, is absolutely in line with the planned production. In selecting potential areas for the establishment of forest plantations, strict attention was paid to the current use of the available areas. The study area includes the areas that can be determined but are not necessarily required for the needs of such production. Out of a wide range of autochthonous and allochthonous species, the tree species that are most capable of exploiting the potentials of the site and provide high energy values in the given ecological conditions were selected.
\end{abstract}

Key words: forest plantations for energy needs, potential vegetation, tree species;

\footnotetext{
${ }^{1}$ Institute of Forestry, 3 Kneza Višeslava, Belgrade, Serbia
} 


\section{IZDVAJANJE POTENCIJALNIH POVRŠINA ZA OSNIVANJE ŠUMSKIH ZASADA ZA ENERGETSKE POTREBE NA PRIMERU OPŠTINE LAZAREVAC}

Izvod: Potrebe za energentima u Srbiji se stalno povećavaju. Drvo kao najznačajniji energent ne koristi se samo za energetske potrebe, već $i$ za potrebe drvne industrije, te je jasno da se sve više povećava pritisak na pomenuti resurs. Po metodologiji FAO procenjena energetska vrednost potencijalno raspoložive biomase iz šumarstva $i$ drvno-prerađivačke industrije u Srbiji iznosi ukupno 1,53 Mtoe/godišnje (BrašanacBosanac et al., 2018). Institut za šumarstvo Beograd je 2016. godine uradio preliminarnu studiju o osnivanju šumskih zasada za energetske potrebe, a kao idejni pilot projekat za osnivanje šumskih zasada za energetske svrhe izabrana je opšrina Lazarevac. Procenjeno je da ova opština, s obzirom na njen geografski položaj i ekološke uslove apsolutno odgovara planiranoj proizvodnji. Prilikom izdvajanja potencijalnih površina za osnivanje šumskih zasada, strogo je vođeno računa o dosadašnjoj nameni i korišćenju raspoloživih površina. Predmet rada su površine koje je moguće, ali ne i nužno izdvojiti za potrebe ovakve proizvodnje. Iz širokog spektra autohtonih $i$ alohtonih vrsta, izdvojene su vrste drveća koje najbolje koriste potencijal staništa i obezbeđuju visoku energetsku vrednost $u$ datim ekološkim uslovima.

drveća

Ključne reči: šumski zasadi za energetske potrebe, potencijalna vegetacija, vrste

\section{INTRODUCTION}

In 2016, the Institute of Forestry in Belgrade conducted a preliminary study to allocate potential areas for the establishment of forest plantations for energy needs in Lazarevac municipality. It was estimated that the geographical location and ecological conditions of the municipality are absolutely in line with the planned production. In addition, the municipality in question, as no other in Serbia, is characterized by large complexes of anthropogenic surface areas of deposols caused by surface coal mining. Due to their physical and chemical composition, these soils are often not suitable for agricultural production. Furthermore,the entire area is exposed to severe air and water pollution. The establishment of the plantatiosn of forest tree species for energy needs is highly desirable in these circumstances. In addition, they will contribute to the increase in green areas of Belgrade.

\section{RESEARCH AREA}

\subsection{General natural characteristics of the area}

The Municipality of Lazarevac has a very favorable geographical position. It is located $55 \mathrm{~km}$ south-southwest from Belgrade. Stubički Vis with an altitude of $393 \mathrm{~m}$ is the highest point in the municipality. The city of Lazarevac is at an altitude of $147 \mathrm{~m}$, and the lowest point in the municipality $(87 \mathrm{~m})$ is where the Kolubara river passes to a neighboring municipality. The favorable geographical position ensures that the municipality has good traffic communication with Belgrade and central Serbia through the Ibarska highway and the Belgrade-Bar 
railway (Rakonjac et al., 2011). According to authors (Ducić et al., 2005), this area belongs to the continental climate. Air temperature extremes range from $-32.6^{\circ} \mathrm{C}$ to $42.3^{\circ} \mathrm{C}$. According to the data of the Belgrade-Košutnjak hydrometeorological station, the mean annual air temperature in this area is $12.3^{\circ} \mathrm{C}$, while it is $18.93^{\circ} \mathrm{C}$ in the growing period. The mean annual rainfall is about $696.1 \mathrm{~mm}$, while in the growing period it amounts to about $395 \mathrm{~mm}$. As a result of surface coal mining and the work of Veliki Crljeni thermal power plant, meso- and microclimate conditions, as well as the air quality, have been significantly changed. According to authors (Rakonjac et al., 2011), the terrain of the municipality of Lazarevac is inclined towards the Kolubara River which flows along the western border of the municipality. The northwestern part of the municipality is flatland, and the southeast is hilly.

In the area of Lazarevac municipality, the following units can be distinguished:

The flatland zone, up to $100 \mathrm{~m}$ above sea level, covers $15-20 \%$ of the territory in the northwest of the municipality (the catchment area of the Kolubara River). The areas that are mainly located near watercourses and are not used for agricultural purposes were selected for the establishment of forest plantations for energy needs. These are mostly abandoned and uncultivated agricultural lands and barrens with or without natural vegetation. These are also the largest complexes envisaged for energy plantations.

The lower Šumadija-hilly zone, from 100 to $200 \mathrm{~m}$ above sea level, covers most of the municipality (65\% of the territory). In this zone, the areas that are not optimally used for agricultural production are selected for the establishment of forest plantations for energy needs. These are usually barrens, with or without natural vegetation, or abandoned agricultural or forest land.

The higher Šumadija hilly zone, over $200 \mathrm{~m}$, occupies the central portion of the southern part of the municipality (20\% of the territory). In this zone, smaller areas of predominantly barren forest lands are selected.

In the immediate vicinity of the town of Lazarevac, artificial Lake Očaga was constructed. More than 10 lakes have been formed in the depressions of unregulated mine spoil banks of open-pit mine site - field ' $D$ '. In the territory of the Municipality of Lazarevac, there are numerous small lakes and swamps formed in the old riverbeds of the Kolubara River and its tributaries, known as 'oxbow lakes` ('dead or stagnating water), while some resulted from the exploitation of coal or sand. These lakes can serve as water reservoirs for irrigation in dry seasons (Dražić, 1997). According to the geological map of Serbia and previous research (Miletić, 2004), the area of the municipality was built from different rocks in terms of the geological age and mode of occurrence, as well as in terms of their petrographic and chemical composition. In terms of geology, the oldest rocks include Paleozoic crystalline shales, triad and cretaceous limestone, sandstone and marl. The hilly terrain developed on these rocks. The lower hilly and flatland terrains comprise tertiary and quaternary sediments consisting of sand, clay, sandstone, limestone, loam, gravel, infusion ground and coal.

In the territory of the municipality of Lazarevac, terrestrial soil types are represented by eutric vertisols, eutric cambisols and luvisols, while hydromorphic soil types include fluvisols, gleysols, meadow soils, gleyic chernozems cambisols 
gleyc and gleysols molic soil. Besides the natural soil types, large areas of the territory of Lazarevac municipality are covered with anthropogenic soil. Above all, they are represented by deposols that originate from the waste deposited on the open-pit coal mine sites and occupy large areas. Deposols (mine soils) of the area are the soils of poor productivity because they are poor in plant nutrients that are readily available to plants. In addition to deposols, technosols can also be found. These are soils formed by the disposal of the products from industrial and technological processes. These soils include technosols which result from coal combustion in thermal power plants and the sludge dumps that result from by coal washing. These soils occupy very small areas in the municipality (Miletić, 2004).

\subsection{The status of forests and forest land}

According to the data obtained from the Forest Management Plan (General forest management plan for Podrinje - Kolubara forest area (2004 - 2013)), about $18 \%$ of the territory, i.e. 7, 024 ha, are covered in forest, about 800 ha of which are plantations established in the period between 1973 and 1993 during the recultivation of mine spoil banks, and to a lesser extent ash dumps (35 ha). In the selected area there are 3,100 ha of forests, which makes up 5.7\% of the total area of the municipality.

These are mostly coppice forests whose composition has been changed compared to their natural potential and fragmented into a large number of small areas. Most of the forests are privately-owned. Hilly terrains are dominated by elm and common maple, whereas in the lowland, Hungarian oak and Turkey oak are the most abundant species. In the forest stands that are found on deposols, the most common are pure black pine plantations (Pinus nigra) and those of scots pine (Pinus silvestris), followed by mixed plantations of various conifers. Pure plantations consisting of other species of conifers (Larix europaea, Larix japonica, Pseudotsuga menziesii, Pinus strobus) occupy small areas. There are occasional plantations of broadleaved tree species (Quercus robur, Quercus petraea, Acer pseudoplatanus, Acer negundo, Alnus glutinosa, Fraxinus excelsior and others).

Apart from Weymouth pine and occasionally black pine plantations, the forests raised on the mine spoil banks are mostly very vital and of good health. The processes of soil restoration, oxygen infiltration, regulation of infiltration and surface runoff, decomposition of organic matter and humus formation have been initiated (Miletić, 2004).

The following tables give an overview of the areas by their land use categories, with particular reference to the structure of forest areas.

Table 1. Relation of existing and planned areas by category of land use in

Lazarevac municipality

\begin{tabular}{|c|c|c|c|c|c|c|c|c|c|c|}
\hline \multirow{3}{*}{ 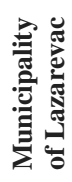 } & $\mathbf{A} / \mathbf{k m}^{2}$ & $\begin{array}{l}\text { Surface } \\
\text { balance }\end{array}$ & $\begin{array}{c}\text { Building } \\
\text { land }\end{array}$ & $\%$ & $\begin{array}{c}\text { Agricul. } \\
\text { land }\end{array}$ & $\%$ & $\begin{array}{c}\text { Forest } \\
\text { land }\end{array}$ & $\%$ & Other & $\%$ \\
\hline & \multirow{2}{*}{37.54} & existing & 3.85 & 10.26 & 21.92 & 58.38 & 11.34 & 30.21 & 0.43 & 1.15 \\
\hline & & planned & 3.85 & 10.26 & 21.62 & 57.59 & 11.34 & 30.21 & 0.36 & 0.96 \\
\hline
\end{tabular}

Source: Regulation on the establishment of the Spatial Plan for the area of special purpose - infrastructure corridor Belgrade-South Adriatic, section Belgrade-Požega, "RS Official Gazette" vol. 37/2006, 31/2010 
Table 2. State forests by basic categories of land use

\begin{tabular}{|c|c|c|c|c|c|c|c|c|}
\hline \multirow{3}{*}{ 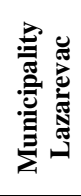 } & \multirow[b]{2}{*}{$\begin{array}{l}\text { Total } \\
\text { area } \\
\text { (ha) }\end{array}$} & \multicolumn{3}{|c|}{ Forests and forest land } & \multicolumn{3}{|c|}{ Other land } & \multirow[b]{2}{*}{$\begin{array}{l}\text { Occupied } \\
\text { land }\end{array}$} \\
\hline & & Total & $\begin{array}{l}\text { Natural } \\
\text { and } \\
\text { artificial } \\
\text { forests }\end{array}$ & $\begin{array}{l}\text { Forest } \\
\text { land }\end{array}$ & Total & $\begin{array}{l}\text { Infertile } \\
\text { land }\end{array}$ & $\begin{array}{l}\text { For other } \\
\text { purposes }\end{array}$ & \\
\hline & 1311,37 & 1184,40 & 1102,34 & 82,06 & 126,97 & 46,88 & 80,09 & - \\
\hline
\end{tabular}

Source: General forest management plan for Podrinje - Kolubara forest area (2004 - 2013)

According to the natural, spatial and functional needs and requirements of the forests in the area, the areas of forests and forest lands are allocated according to their priority functions to the following units:

- unit '10', intended for the production of technical wood, was established on the surface area of 392.94 ha or $36 \%$ of the total forest area;

- unit '12', production-protection forests, was established on the surface area of 158.20 ha or $14 \%$ of the total forest area;

- unit '16, a large game hunting and breeding center, was established on an area of 356.85 ha or $32 \%$ of the total forest area;

- unit '18', intended for the production of other products (lignite production), was established for the needs of coal exploitation on an area of 185 ha or $17 \%$ of the total forest area;

- unit ' 26', intended for soil conservation of degree I;

- unit `66, intended for permanent forest protection and represented by a much smaller area compared to other units.

\subsection{Potential vegetation in the municipality of Lazarevac}

The potential natural vegetation of Lazarevac municipality comprises the following forest communities:

1. The willow and poplar forest - Populeto-Salicetum Paradis. 1950. The community of willow and poplar in the area of Lazarevac represent potential natural vegetation on smaller riparian areas of the rivers of Kolubara, Tamnava, Turija and Peštan and their tributaries, where the influence of flooding and ground waters is very pronounced.

2. The monodominant forest of narrow-leaved ash - Fraxinetum angustifoliae Vuk. 1959. These forests occupy depressions in which water has been stagnationg for a long time.

3. The forest of narrow-leaved ash and spreading elm - Fraxino angustifoliae-Ulmetum effusae Slav. 1952. These forests occupy considerable foreland areas with a pronounced oscillation of groundwater resulting in the abrupt terrain drainage.

4. Forest of pedunculate oak with narrow-leaved ash - Fraxino angustifoliae-Quercetum roboris B. Jov. et Tom. 1979. These forests occupy a belt between the hygrophilous willow and poplar forests in the riparian zone and mesophilous pedunculate oak and common hornbeam forests which cannot be reached by flood waters. 
5. The forest of pedunculate oak - Genisto elatae-Quercetum roboris Horv. 1938. The forests of pedunculate oak occupy lower terrains, sufficiently moist due to high groundwater levels, which can be periodically flooded.

6. The forest of pedunculate oak and common hornbeam - Carpino betuli-Quercetum roboris Anić 1959. Pedunculate oak and common hornbeam forests occur in fragments in the Kolubara basin, being a transition variant between hygrophilous pedunculate oak forests and zonal forests of Hungarian oak and Turkey oak. Groundwater is present at a depth of $2-3 \mathrm{~m}$. The community is speciesrich.

7. The Hungarian oak and Turkey oak forests - Quercetum farnettocerris Rud. 1949. The community forms potential natural vegetation in the largest part of the municipality. It is a climax community of Serbia. It is found on eutric cambisols, eutric vertisols, luvisols and planosols.

8. Forest of sessile oak and common hornbeam - Querco-Carpinetum moesiacum Rud. 1949. Sessile oak and common hornbeam forests occur in the area as a variant of extrazonal vegetation, at lower altitudes, in shaded cool valleys, on wet and cold exposures in the zone of climax forests of Hungarian oak and Turkey oak.

According to the phytosociological research (Miletić, 2004) and based on the floristic composition of natural vegetation, the potential natural vegetation of MEC (Mining and Energy Company) 'Kolubara' include four different communities: Quercetum farnetto-cerris Rud. 1949, Carpino-Quercetum robori cerridis Jov. 1967, Ulmeto-Quercetum roboris B. Jov. 65. and PopuletoSalicetum Paradis. 1950.

\subsection{The actual vegetation in the municipality of Lazarevac}

According to the research done by (Vučković, 1986), in the area of Lazarevac municipality, the actual vegetation consists of the following forest communities:

1. White willow forests - Salicetum albae Issl. 1936.

2. Forests of common oak - Genisto elatae-Quercetum roboris Horv. 1938.

3. Forests of common oak and common hornbeam - Carpino betuliQuercetum roboris Rauš 1971.

4. Forest of common oak, common hornbeam and Turkey oak with limes - Carpino betuli-Quercetum roboris tilietosum tomentosae Rauš 1969.

5. Forests of sessile oak and common hornbeam with butcher's broom Querco-Carpinetum aculeatetosum Jov. 1951.

6. Forests of sessile oak and common hornbeam with Hungarian oak Querco-Carpinetum quercetosum frarnetto Gaj.

7. Submontane beech forests - Fagetum submontanum Jov. 1967. cerris Rud. 1949.

8. Forests of Hungarian oak and Turkey oak - Quercetum farnetto-

9. Sessile oak forests - Quercetum montanum Cher. et Jov. 1953.

10. Forests of sessile oak with moss - Quercetum montanum muscetosum Slav. 


\section{MATERIALS AND METHODS}

Potential areas for the establishment of forest plantations for energy needs were allocated with close attention to the current purpose and use of the available areas. Forests were not taken into consideration unless they were small fragments of scattered and degraded woodlots that prevented the formation of larger units of energy plantations. The ones that are accessible and enable the formation of larger units of energy plantations were selected. Areas that were not actively used for agricultural purposes were selected, as well. These were abandoned, uncultivated areas and possibly extensively managed plots. Finally, areas of uncultivated mine spoil banks were selected for energy plantations. These were the input elements based on which the criteria for the selection of about 2000 hectares of areas suitable for the establishment of the plantations were defined.

The main criteria based on which suitable areas were selected and classified are the following:

- to avoid a reduction in active agricultural production;

- to introduce some production into the uncultivated and abandoned areas;

- to make abandoned and uncultivated areas suitable to be used for agricultural production again and without major investments;

- to ensure that selected areas are accessible by heavy and easy mechanization and that the mechanization can move on them despite the slope of the terrain and other conditions;

- to ensure that the selected areas have a predefined minimum surface area. Selected areas of less than 1 ha could be taken into consideration only if they are located near the mainland or near a road which makes them readily accessible.

According to the listed criteria, all selected areas can be classified into the following categories: barrens, barrens with natural vegetation, neglected lands, areas with extensive agriculture, scattered and devastated forests and mine spoil banks.

Barrens are areas that are not cultivated and used for any plant production. Within them, the selected areas are located close to roads and watercourses, as well as the areas that could be merged with other suitable surface areas to make larger units and achieve the profitability of the establishment, maintenance and exploitation of energy plantations

Neglected land is represented by areas that were once used for agricultural purposes. However, due to the abandonment of rural households, they have not been used for agricultural production for a long time. They are mostly overgrown with weeds and they do not fully exploit the site potentials.

The areas of extensive agricultural production are similar to the previous ones as they also do not fully exploit the potentials of the site. Such areas were taken into consideration only if the formation of larger units consisting of previously selected areas was required.

As in the case of the previous ones, devastated forests were considered only if they consisted of smaller fragments that intersected with the selected and more suitable areas. 
Finally, mine spoil banks which are result of coal mining were also considered to be suitable areas for energy plantations. These are disturbed natural sites with different bedrocks.

Selection of species for the establishment of energy plantations was done with special attention to the ecology of species and their energy values.

\section{RESULTS AND DISCUSSION}

\subsection{The structure of the areas selected for energy plantations in terms of geological conditions}

The selected areas have a highly diverse bedrock. In terms of geology, mine spoil banks are most represented in the selected areas. They include soils that are designated as deposols. Based on the previous research and the fieldwork designed and conducted by the Institute of Forestry, it can be concluded that they are suitable for the selected tree species (Dražić, 1997; Miletić, 2004). Mine spoil banks account for about $1 / 4$ of the areas selected for forest plantations for energy needs. The species that have had the best performance on the bedrock mentioned are the black alder and the birch.

Following the mine spoil banks, gravel, sand, alevrolite and pelitolyte in the riparian area of the alluvial plain are most frequently occurring. This formation occupies about $1 / 4$ of the total area. Depending on other ecological conditions of these bedrocks, the following species are selected: narrow-leaved ash and red oak (hardwood species), black alder (medium hardwood species) and poplar and willow (soft hardwood species) species.

The slightly higher parts of the alluvial plain are composed of marly clay, charcoal clay, diatomaceous soil and sand. Depending on the type of soil and potential vegetation, energy plantations of predominantly hardwoods (red oak, common hornbeam, black locust) are planned. Soft hardwoods include black alder and poplar trees although on a smaller scale and in specific conditions.

On the elevated terrains, the selected areas are represented by clay, sand and rarely gravel (Pannonian). They are suitable for hard hardwoods. The red oak was selected for the lower parts where groundwater still occurs. For the mesophilous conditions of higher terrains, the common hornbeam is selected as a species with the highest energy value. For the southern aspects, the black locust is selected.

Other bedrocks are less frequent in the area and they occur in the mountainous belt of the municipality of Lazarevac.

\subsection{The structure of the areas selected for energy plantations in terms of soil conditions}

Under the influence of different geological substrates and other pedogenetic factors, different soil types were formed on the selected areas for energy plantations. Depending on the method of moistening the soil profile, semiterrestrial (in the flatland area of the alluvial plain) and terrestrial soils (in the mountainous part of the area) occur in the entire area of Lazarevac municipality. 
The most frequent soil type selected for the establishment of fastgrowing energy plantations is deposol. Based on previous experience, black alder and birch would be the most suitable species for energy plantations.

Semi-terrestrial soils are more abundantly present than the terrestrial ones and the largest area is occupied by fluvisols. The following species are selected for these soil types: narrow-leaved ash, black alder, poplar, willow and red oak. In the alluvial plain, there are planosols, gleyic planosols and eutric cambisols. On these types of soil, the following species of trees are most frequently used: poplar, red oak, narrow-leaved ash and black alder.

Among the terrestrial soils in the mountainous zone, dystric cambisol is most commonly occurring in the isolated areas. The most frequently used tree species on this type of soil are lime, common hornbeam and aspen. There is also eutric cambisol, with the following tree species most frequently used: black locust, common hornbeam, aspen, lime and red oak.

Soils such are planosols, luvisols and dystric cambisol occupy smaller areas. They are suitable for the following tree species when establishing plantations for energy needs: common hornbeam, aspen, red oak and black locust.

Other soils such are eutric vertisols and calcaric cambisols are very rare in the selected areas.

\subsection{The structure of the areas selected for energy plantations based on the potential vegetation}

Potential vegetation combined with edaphic conditions is a key environmental factor for the selection of tree species for forest plantations for energy purposes.

In the lowest flatlands, the selected areas are within the sites of potential vegetation of poplar and willow forests. Forest plantations of black alder and willow are planned to be established there. There are few such areas.

In the depressions of alluvial plains, these are followed by the areas of potential vegetation of narrow-leaved ash forests with a very high level of groundwater. The following species are planned in this area: narrow-leaved ash and black alder. The sites with a lower level of groundwater, though still high, belong to the potential vegetation of common oak and narrow-leaved ash forests. The most common species selected for these sites are narrow-leaved ash, common alder, poplar, red oak and willow.

Drier sites of alluvial plains belong to the potential vegetation of pure common oak forests. The most frequent species selected for these sites are common alder, red oak, poplar, narrow-leaved ash and common aspen.

Micro-hills are occupied by the sites of common oak with common hornbeam. The most common species selected for these sites are red oak, common alder, poplar and common hornbeam.

In the mountainous part of the region, the more frequent one is the site of the climax forests of Hungarian oak and Turkey oak. In the mesophilous ecological conditions, on the sites of potential vegetation of Hungarian oak and Turkey oak, plantations of common hornbeam trees are planned to be established, in the most xerophilic ones the black locust, and in the transitional ones the common 
aspen and the lime. For the mesophilic sites of beech, the intensive common hornbeam plantations are selected.

\subsection{The structure of the areas related to the current land use}

Within the areas selected for energy plantations, about 1/3 of the total area is barren land. The barrren land which has not been used for plant production for a long time has stands of low-value spontaneous forest vegetation. If they are located in accessible places or there is a possibility to merge them with other suitable areas, these areas are also selected for the establishment of forest plantations for energy needs. Isolated areas, as well as those that are more difficult to access, are left for afforestation. Barren land and barren land with spontaneous natural vegetation occupy about $58 \%$ of the selected area.

The uncultivated and abandoned areas are not optimally used in agricultural production. Therefore they could be temporarily used for the establishment of forest plantations for energy needs due to their short production cycle. However, if necessary, they could be returned to agriculture. Such areas in the municipality of Lazarevac occupy about $7 \%$ of the total area.

In the municipality of Lazarevac, areas with extensive agricultural production that are allocated for the establishment of forest plantations for energy needs occupy about $6 \%$ of the total area. These are predominantly areas of lower fertility classes used as pastures and the ones that produce low agriculture yields.

Devastated forests were mostly avoided. They are selected only exceptionally $(2 \%)$ for the establishment of forest plantations for energy needs to merge larger complexes.

Physical properties and chemical composition of mine spoil banks may be unsuited for agricultural production. Establishment of forest plantations for energy needs is another optimum way of their utilization and recultivation. In the municipality of Lazarevac, about $27 \%$ of the total area is represented by these areas. Selecting the appropriate dendroflora species, method of setting up the protection zone and technological procedure for soft landscaping of plateaus and slopes will result in restoration and strengthening of natural components, creation of more favorable microclimatic conditions, protection of land from erosion, protection of the open pit surrounding area from air pollution, and creation of visual barriers and habitats for the return of the old and arrival of the new plant and animal species (Čule et al., 2013).

\subsection{Tree species selected for the establishment of energy plantations}

From a wide range of autochthonous and allochthonous species, it was necessary to select tree species that would optimally use the potentials of the site and provide high energy values in the given ecological conditions. Accordingly, the following criteria were defined:

1. It is necessary to respect the ecology of species and available sites;

2. It is necessary to select species according to their energy values; 
3. Priority should be given to autochthonous broadleaved species which will not degrade the sites and can be easily replaced with other species, if there is a need to change the purpose of the area;

4. Selected species should have a meliorative impact on the soil (regulation of the level of groundwater, erosion control, soil structure improvement and enrichment with organic matter and nitrogen).

In conformity with the criteria mentioned, the municipality of Lazarevac was divided into a flatland and a hilly zone:

1. In the flatland zone beside the rivers in the alluvial plains with the highest level of groundwater, at the sites of white willow, black alder and less often of common oak with black alder the following species are proposed: Salix viminalis, Alnus glutinosa and Fraxinus angustifolia; According to previous experience in the recultivation of deposols in the area planned and carried out by the Institute of Forestry, black alder proved to be very productive. In addition, this species has a very favorable effects on the improvement of anthropogenic sites [3].

2. Regarding the higher terrains, on willow and poplar sites and in small parts of common oak sites, rapid-growing clones of the Euroamerican poplar are selected (Populus euroamericana cl. I-214);

3. In the area of common oak sites, red oak (Quercus rubra) is most commonly selected;

4. In alluvial deposits of higher terrains, on the sites of potential vegetation of common oak and hornbeam, the common hornbeam (Carpinus betulus) is selected for planting; These sites are still under a certain influence of groundwater on semi-terrestrial soils, thus a significant growth increment of common hornbeam as a species with the highest energy value is expected here.

5. In the pre-hilly zone where common oak is present either individually or in groups, plantations of red oak (Quercus rubra) are planned to be built; This is a species with high coppice vigor and rapid growth in youth.

6. Common hornbeam (Carpinus betulus) is also selected on the sites of potential montane beech vegetation of the hilly zone;

7. The common hornbeam is also selected for the mesophilous sites with deeper soil and shaded aspects of the sites of potential vegetation of Hungarian oak and Turkey oak with common hornbeam;

8. For the transitional sites with more favorable ecological conditions and deeper soils of potential vegetation of Hungarian oak and Turkey oak, silver lime (Tilia argentea) is proposed;

9. The barren lands or abandoned agricultural lands of the hilly zone are planned to be planted in common aspen (Populus tremula)

10. On the driest sites of potential vegetation of Hungarian oak and Turkey oak forests with southern aspects and shallow and skeletal soils, black locust (Robinia pseudoacacia) is selected; It was difficult to find an adequate species that suits the low potentials of the site, that is fast-growing, has high coppice vigor and high energy value. In this case, although it is an allochthonous and invasive species, black locust was the best choice.

11. In the hilly zone, another pioneer species showed good results, especially on the mine spoil banks which were formed due to the surface coal mining. It is the birch (Betula verucosa). It has a very high tolerance to deposols, 
high-acidity soils and the presence of coal in the substrate. The species itself spontaneously colonize these sites. It has a rapid growth in youth and a high rate of coppice growth.

\section{CONCLUSION}

There is a growing need for renewable energy in the whole world. Wood is an important, renewable, natural source of energy. Therefore, the demand for the establishment of fast-growing plantations for energy is growing rapidly.

The municipality of Lazarevac is located near Belgrade. The road network is relatively well-developed. The territory of the municipality is characterized by a low percentage of forest cover $(5.7 \%)$. Due to its high population, the need for renewable energy sources is increasing.

In selecting areas for establishing forest plantations for energy needs, we focused on the areas that are not optimally used in agricultural production or agriculture is only extensive. These are generally areas of lower fertility. In addition, we selected areas that were connected in larger complexes and located along the existing roads allowing the application of easy and heavy mechanization.

The natural conditions (relief, hydrography, climatic and edaphic conditions) enabled the selection of a wide range of tree species for the needs in question. In proposing species for energy purposes, besides their energy value, special attention was paid to the ecology of species in relation to the ecological conditions in each specific case.

Given that Serbia has no experience in the establishment of forest plantations for energy needs, the plantations in Lazarevac municipality could be used as a test site for further research.

\section{REFERENCES}

Brašanac-Bosanac, Lj., Ćirković-Mitrović, T., Eremija, S., Stajić, S., Lučić, A. (2018): Improving the use of forest-based biomass for energy purposes in Serbia, Sustainable Forestry, Collection 77-78, pp. 113-122

Čule, N., Dražić, D., Veselinović, M., Brašanac-Bosanac, Lj., Mitrović, S., Nešić, M. (2013): Biological reclamation of landscape degraded by surface mine exploitation -case study of coal surface mine "Tamnava - Zapadno polje", Sustainable Forestry, Collection 67-68, pp. 103-115

Ducić, V., Radovanović, M. (2005): Climate of Serbia, Institute for textbooks and teaching aids.

Dražić, D. (1997): The study of the status and functionality of reclaimed landfill afforestation in the area of Kolubara basin in order to improve the environment and its use for recreation. PhD thesis. Faculty of Forestry in Belgrade.

Miletić, Z. (2004): Development of land in landfills in REIK Kolubara under the influence of forest plantations. PhD thesis. Faculty of Forestry in Belgrade. 1-267 
Vučković, B. (1986): The vegetation characteristics of the area around the industrial facilities REIK "Kolubara", as a natural basis for establishing greening standards, Proceedings of the Institute of Forestry and Wood Industry, collection tom XXVI-XXVII, Belgrade.

Rakonjac, Lj., Ratknić, M., Veselinović, M., Miletić, Z., Ćirković-Mitrović, T., BrašanacBosanac, Lj., Čokeša, V., Stajić, S., Popović, V., Radulović, Z., Jović, Đ., Bilibajkić, S., Braunović, S., Cvejić, M., Čule, N., Mitrović, S., Ratknić, M., Zvonarić, N. (2011): "Development of a plan of afforestation of Belgrade" The report, City Municipality Lazarevac. 1-49

Regulation on the establishment of the Spatial Plan for the area of special purpose infrastructure corridor Belgrade-South Adriatic, section Belgrade-Požega, "RS Official Gazette" vol. 37/2006, 31/2010

General forest management plan for Podrinje - Kolubara forest area (2004 - 2013).

\title{
SELECTION OF POTENTIAL AREAS FOR THE ESTABLISHMENT OF FOREST PLANTATIONS FOR ENERGY NEEDS - THE CASE OF LAZAREVAC MUNICIPALITY
}

\author{
Branka SPASOJEVIĆ, Đorđe JOVIĆ, Vlado ČOKE ̌́A, Jelena UROŠEVIĆ, \\ Filip JOVANOVIĆ
}

\section{Summary}

In 2016, the Forestry Institute in Belgrade carried out a preliminary study on the establishment of forest plantations for energy needs. As a pilot project for the establishment of forest plantations for energy purposes, the municipality of Lazarevac was selected. In selecting potential areas for the establishment of forest plantations, strict attention was paid to the current use of the available areas. The subject of the work is the area that is possible, but not necessarily, for the needs of such production. From a wide range of autochthonous and allochthonous species, tree species were selected that are the most capable to exploit the potentials of the habitat and provide high energy values in the given ecological conditions. Given that Serbia has no experience in the establishment of forest plantations the plantations in Lazarevac municipality could be used as a test site for further research.

\section{IZDVAJANJE POTENCIJALNIH POVRŠINA ZA OSNIVANJE ŠUMSKIH ZASADA ZA ENERGETSKE POTREBE NA PRIMERU OPŠTINE LAZAREVAC}

\author{
Branka SPASOJEVIĆ, Đorđe JOVIĆ, Vlado ČOKE ̌̌A, Jelena UROŠEVIĆ, \\ Filip JOVANOVIĆ
}

\section{Rezime}

Institut za šumarstvo Beograd je 2016. godine uradio preliminarnu studiju o osnivanju šumskih zasada za energetske potrebe, a kao idejni pilot projekat za osnivanje šumskih zasada za energetske svrhe izabrana je opšrina Lazarevac. Prilikom izdvajanja potencijalnih površina za osnivanje šumskih zasada, strogo je vođeno računa o dosadašnjoj nameni i korišćenju raspoloživih površina. Predmet rada su površine koje je moguće, ali ne 
i nužno izdvojiti za potrebe ovakve proizvodnje. Iz širokog spektra autohtonih i alohtonih vrsta, izdvojene su vrste drveća koje najbolje koriste potencijal staništa i obezbeđuju visoku energetsku vrednost u datim ekološkim uslovima. S obzirom da u Srbiji nemamo dovoljno iskustva sa osnivanjem šumskih zasada za energetske potrebe, osnovani šumski zasadi na području opštine Lazarevac bi u budućnosti mogli poslužiti kao ogledni poligon za dalja istraživanja. 